DOI https://doi.org/10.15589/znp2021.1(484).5

UDC 621.43.031.3(045)

\title{
TECHNOLOGY OF CLEANING THE FLOW PART OF GAS TURBINE ENGINES FROM CONTAMINATION
}

\section{ТЕХНОЛОГІЯ ОЧИЩЕННЯ ПРОТОЧНОЇ ЧАСТИНИ ГАЗОТУРБІННИХ ДВИГУНІВ ВІД ЗАБРУДНЕНЬ}

\author{
Michael O. Olali \\ diamant1@ukr.net \\ ORCID: 0000-0003-2548-8551 \\ Evans F. Osaisai \\ fevensosaisai@gmail.com \\ ORCID: 0000-0001-6787-1116 \\ Nataliya V. Olali \\ diamant1@ukr.net \\ ORCID: 0000-0001-8962-4538
}

\author{
М. О. Олалі, \\ канд. техн. наук \\ Е. Ф. Осайсай, \\ канд. фіз.-мат. наук \\ Н. В. Олалі, \\ канд. фіз.-мат. наук, доцент
}

Niger Delta University, Wilberforce Island, Bayelsa State, Nigeria

Найджа Дельта Університет, о. Вільбефорс, ит. Байельса, Нігерія

\begin{abstract}
One of the determining factors in solving the problem of maintaining the gas-dynamic stability of compressors of gas turbine engines in operating conditions is to maintain the technical condition of the flow part of the engines at a given level with increasing operating time.

Operational experience indicates that of all the operational factors that affect the state of the flow part of the gas turbine engine, only the impact of contamination can be more or less eliminated by performing flushing of the flow part in operationThe study of different methods of cleaning the flowing part shows that the most important issues are the justification of the periodicity of washing and the effectiveness of detergents, the development of ways to introduce detergents into the flowing part, reducing labor intensity and time for washing.

This article investigates the effectiveness of special detergent mixtures for cleaning gas turbine engines from contaminants, based on the generalization of experimental data. The washing process is considered as a result of the manifestation of a complex of physicochemical properties of the detergent. According to Rebinder's theory, the washing ability is determined by two factors: surface activity and surface strength, which depend on the degree of dispersion (colloidity) of the detergent in solution. The washing efficiency of 6 special detergents was investigated and determined.

The technology of washing the flowing part of the gas turbine engine is developed, which regulates the method of making the detergent composition into the flowing part of the gas turbine engine, the mode of engine operation during washing, the choice of optimal solution temperature and duration of the washing process. A method for cleaning the flow part of aviation gas turbine engines is proposed, which does not require preparation of the elements of the flow part and complex tooling.

When developing the washing technology, not only the technical aspect (washing quality) is taken into account, but also the economic one. Determine the optimal duration of flushing and its frequency for the life of the gas turbine engine in operation on the example of the engine NK-8-2U.

The scheme of installation for washing of a flowing part of GTD is developed. The principle of operation of the installation is as follows. Boiled water heated to a temperature of $50-80 \mathrm{oC}$ is supplied from the aircraft tanker via a hose to the faucet fitting. Flushing of the flowing part of the engine is carried out with alternating supply of cleaning solution and clean water when the engine is running in the mode of cold scrolling. Removal of contaminants provides restoration of parameters of the fan and compressors of an internal contour. After washing, the degree of compression of the air by the fan increased by $1.4 \%$, the compressor to $2 \%$.
\end{abstract}

Key words: gas turbine engine; flushing; flowing part; flushing technology; detergent; pollution. 


\begin{abstract}
Анотація. Однією з визначальних факторів при вирішенні задачі підтримки газодинамічної стійкості компресорів газотурбінних двигунів в умовах експлуатації є підтримання технічного стану проточної частини двигунів на заданому рівні при зростанні їх наробітку.

Досвід експлуатації вказує, що з усіх експлуатаційних факторів, які вливають на стан проточної частини ГТД, тільки вплив забруднення може бути з більшим чи меншим ефектом усунений за рахунок виконання промивки проточної частини в експлуатації. Вивчення різних способів очищення проточної частини показує, що найбільш важливими питаннями є обгрунтування періодичності промивки та ефективності миючих засобів, розробка способів внесення миючих засобів в проточну частину, зниження трудомісткості та витрат часу на промивку.

У даній статті досліджено ефективність спеціальних миючих сумішей для очищення ГТД від забруднень, на основі узагальнення експериментальних даних. Процес мийки розглядається як результат прояву комплексу фізико-хімічних властивостей миючого препарату. Відповідно до теорії Ребіндера миючу спроможність визначено за допомогою двох факторів: поверхнева активність та поверхнева міцність, які залежать від степені дисперсності (колоїдності) миючої речовини у розчині. Досліджено та визначено миючу ефективність 6 спеціальних миючих засобів. Розроблено технологію промивки проточної частини ГТД, яка регламентує спосіб внесення миючої композиції в проточну частину ГТД, режим роботи двигуна при промивці, вибір оптимальної температури розчину та тривалості процесу промивки. Запропоновано метод для очистки проточної частини авіаційних ГТД, який не потребує препарування елементів проточної частини та складного інструментального забезпечення.

При розробці технології промивки враховано не тільки технічний аспект (якість промивки), але і економічний. Визначати оптимальну тривалість промивки та іï періодичність за ресурс ГТД в експлуатації на прикладі двигуна НК-8-2У. Розроблена схема установки для промивки проточної частини ГТД. Принцип роботи установки полягає в такому. Підігріта до температури 50-80оС кип'ячена вода подається від водозаправника літаків по шлангу до штуцера змішувача. Промивка проточної частини двигуна проводиться з чергуванням подачі миючого розчину та чистої води при роботі двигуна на режимі холодна прокрутка. Видалення забруднень забезпечує відновлення параметрів вентилятора і компресорів внутрішнього контура. Після промивки ступінь стиснення повітря вентилятором зросла на 1,4\%, компресора - до $2 \%$.
\end{abstract}

Ключові слова: газотурбінний двигун; промивка; проточна частина; технологія промивки; миючий засіб; забруднення.

\section{INTRODUCTION}

One of the defining conditions in solving the problem of maintaining gas-dynamic stability of compressors GTE in the conditions of operation is to maintain the technical state of the flow section of the engines at a given level with an increase in production.

Experience has shown that from all operational factors that pour into the state of the compressor flow section of GTE, only the effect of pollution can be with a greater or lesser effect eliminated due to the running of the washing of the flow section in operation.

\section{ANALYSIS OF RECENT RESEARCH AND PUBLICATIONS}

In the practice of the leading airlines, the washing of the flow section of GTE has been widespread since the 70 s of the 20 th century $[3 ; 4]$. The study of various methods for washing the flow section [5-7] shows that the most important issues are the justification of the frequency of washing and the effectiveness of detergents, the development of methods for introducing detergents into the flow section, reducing the complexity and time consuming for washing. Solving these issues requires a thorough analysis of the causes of pollution and their chemical composition.

\section{INVESTIGATION OF THE EFFECTIVENESS OF SPECIAL DETERGENTS FOR CLEANING THE GTE FROM CONTAMINATION}

In the general case, the process of hard surfaces washing consists of two operations: cleaning, which is the removal of contaminants by some means, and rinsing smooth surfaces with aqueous solutions. The efficiency of the washing process depends on the characteristics of the detergents used, solvents and special liquids, the quality of which must meet certain technical requirements. Regarding the process of the flow part of the gas turbine enginewashing, these requirements can be formulated as follows.

1. High washing capacity and speed.

2. Lack of aggressiveness in relation to construction materials and coatings.

3. Safety in use.

4. Absence of harmful effects on nature and man.

5. Ease of manufacture.

6. Low cost.

7. Possibility of utilization with minimal costs and without environmental consequences.

8. Simplicity in the organization of washing.

9. Stability of physicochemical properties.

Nowadays, there are a large number of different detergents that are designed for the hard surfaces, 


\section{ЕНЕРГЕТИЧНЕ МАШИНОБУДУВАННЯ № 1-2021}

including metal surfaces, washing [1, p. 92], but for a number of reasons they do not fully meet the requirements. Therefore, before proceeding to their analysis, it is necessary to briefly consider the mechanism of detergent action.

Modern theory of detergent action considers the process of washing, as a result of the manifestation of a complex of physicochemical properties of detergent, which includes wetting, emulsifying, foaming, dispersing, solubilizing and stabilizing ability. Detergent capacity of this or that detergent depends on the degree of manifestation of each component. According to Rebinder's theory, the washing ability is determined by two main factors [1, p. 94]: surface activity and surface strength, which depend on the degree of dispersion (colloidity) of the detergent in solution.

The speed and completeness of the removal of contaminants from hard surfaces depend on the nature and condition of the surface. Water hardness, temperature, the presence of polyvalent metal ions in the contamination, the nature and composition of detergents and a number of other factors are also important for the detergent effect $[3$, p. 165]. By their nature, detergents are divided into anionic, cationic, ampholytic and nonionic [3, p. 167]. Anionic substances in aqueous solutions form negatively charged ions (anions), while cations affect the solubility of these substances.

An example of anionic substances may be the disodium salt of sulfosuccinic acid monoester $\mathrm{CH}_{2} \mathrm{COONa}-$ ROOOCCHSO ${ }_{3} \mathrm{Na}$, which is the basis used for washing the flow part of the gas turbine engine NK-8-2U. The detergent "Aerol" and used for the sanitation of aircraft and helicopters; $\mathrm{CH}_{3} \mathrm{RCHSO}_{4}-\mathrm{CHRCH}_{3}$, forming the basis of the paste, which is recommended for rinsing the flowing part of the engine D-30 II series [8, p. 46].

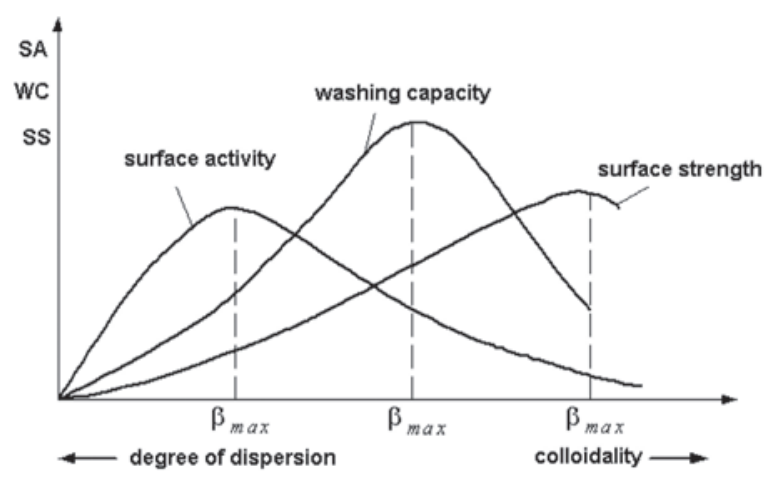

Fig. 1. Dependence of surface activity and surface strength on the degree of colloidal (dispersion) of the detergent in solution

The surface activity of cationic substances is due to positively charged ions (cations). An example of such a substance is ethanolamine soap used for external aircraft washing $\mathrm{R}-\mathrm{CH}_{2} \mathrm{NH}_{2}$, which is obtained by the interaction of oleic acid $\mathrm{C}_{17} \mathrm{H}_{33} \mathrm{COOH}$ and monoethanolamine $\mathrm{NH}_{2} \mathrm{CH}_{2} \mathrm{CH}_{2} \mathrm{OH}$.
Ampholytic compounds contain one or more functional groups, which, depending on the environmental conditions, may acquire the character of an anionic (alkaline medium) or cationic (acidic medium) substance in aqueous solution.

In the isoelectric field, they act as nonionic substances. The dependence of the properties on the $\mathrm{pH}$ value of the solution is determined by the formula

\begin{tabular}{|c|c|c|}
\hline Acidic environment & & $\begin{array}{l}\text { Alkaline } \\
\text { environment }\end{array}$ \\
\hline $\mathrm{RN}+\mathrm{H}_{2} \mathrm{CH}_{2} \mathrm{COOH}$ & $\leftrightarrow \mathrm{RN} \pm \mathrm{H}_{2} \mathrm{CH}_{2} \mathrm{COO} \leftrightarrow$ & $\mathrm{RNH}_{2} \mathrm{CH}_{2} \mathrm{COO}$ \\
\hline cationic properties & $\begin{array}{l}\text { nonionic } \\
\text { properties }\end{array}$ & $\begin{array}{l}\text { anionic } \\
\text { properties }\end{array}$ \\
\hline $\mathrm{H} \leq 4$ & $4<\mathrm{PN}<9$ & $9 \leq \mathrm{PH} \leq 14$ \\
\hline
\end{tabular}

Nonionic substances in aqueous solution do not form ions. The difference in the nature of these groups of detergents determines the scope of their application, so to choose the most effective means it is necessary to consider the elements of process theory and perform a comparative analysis [4, p. 242].

First of all, the choice of detergent determines the nature of the surface and the type of contamination. Since we are talking about washing the compressors of aircraft gas turbine engines, we can limit ourselves to the consideration of blades made of titanium alloys and steels with a surface cleanliness corresponding to 7 ... 11 class. Since contaminants can be present in three physical states (solid, liquid and gaseous), it is of practical importance for detergents to consider the combinations of solid-solid, liquid-solid and gaseous-solid phases.

Contaminants are generally a heterogeneous mixture of substances different in chemical composition and physical properties, and can be divided depending on the possibility of their removal during cleaning into four main groups:

1. Water-soluble polar compounds (inorganic salts, organic acids, some organic substances).

2. Water-insoluble inorganic compounds (cement, dust, soot, clay, silicates).

3. Hydrocarbons (kerosene, oil, resins, asphalt, paints, varnishes, various fats).

4. Water-insoluble polar organic compounds, mainly fatty acids.

There are primary particles of mineral contaminants (size up to $3 \ldots 5 \mu \mathrm{m}$ ) and secondary particles formed by agglomeration of primary. These are chaotically constructed particles (size up to $10 \ldots 50 \mu \mathrm{m}$ ) with large cracks, into which solutions of colloidal electrolytes penetrate and disperse these particles. Thus, diffraction patterns of contamination samples taken on the compressor blades of NK-8-2U engines [3, p. 166; 8, p. 42 ] showed the presence of oxides and hydroxides of metals, carbon deposits, organic and mineral water-soluble substances, quartz, gypsum, rutile, talc, mica, hematite. pentlandite, metallic lead, feldspars. 
The majority are primary particles with a size of $10 \ldots$ $25 \mu \mathrm{m}$, namely $12 \%$. The rest are water-insoluble oily-resinous and organo-polar contaminants, which connect the contaminant particles into a dense mass. The presence of salts of heavy metals, corrosion products and residual resins of lubricating oils is also noted, which indicates the presence of a chemical interaction between the contaminants and the metal of the blades. Therefore, consideration of the washing process should begin with consideration of adsorption.

Adsorption occurs under the action of chemical forces or forces acting at the interface of two phases. Therefore, during adsorption, various processes can take place, the end result of which is the retention of one substance to another.

Adsorption of substances on the interface is their main property. If molecules or ions that include one or more groups have affinity in the phase in which they are dissolved or dispersed, and, in addition, include one or more groups that have repulsive forces relative to the dissolved medium, then such molecules or ions are able to accumulate on the interface. Surfactants have this property. An accumulation of detergent molecules passes on liquid-gas phase separation [4, p. 252]. As a result, the surface tension of the water is reduced and foam may form. On the liquid-liquide phase separation (for example when emulsifying oil in water) hydrophobic chains are directed to the hydrophobic drop of oil, the surface is hydrophilized by solvating groups resulting in reduced interfacial surface tension between two insoluble liquids.

On the solid-solid phase separation (metal particles of contaminants), the same oriented adsorption takes place. The thermodynamic relationship between the concentration of solute on the surface C1 [4, p. 178], the concentration in solution $\mathrm{C}$ and the interfacial surface tension is determined by the Gibbs equation $C_{1}=\frac{C}{R T} \frac{d \sigma}{d C}$, where $R$ - gas constant; $T$ - temperature; $\sigma$ - surface tension.

It follows that with increasing degree of adsorption (the solution is depleted of detergent) the surface tension at the phase boundary increases. From the point of view of the processes taking place at the phase boundary, the following properties are of practical importance: wetting, emulsification, (dispersing), foaming, solubilization and cleaning action.

Wetting is the displacement of any other phase by a liquid phase from a solid or liquid body. The behavior of a drop lying on a solid surface is determined by the forces of surface tension. Under the action of these forces, the boundary line moves with a simultaneous change in the shape of the drop until equilibrium. If equilibrium is reached at the value of the edge angle $\varphi_{A}$, then the algebraic sum of the acting forces must be zero [5, p. 25]:

$$
-\sigma_{A S}-\sigma_{A} \cos \phi+\sigma_{S}=0 \text {. }
$$

With a change $\varphi_{A}$ the amount of wetting changes. In the presence of a number of surfactants, the wetting rate can increase significantly. The processes that take place in this case are quite complex, so let's just say that one of the functions of surfactants in detergents is to accelerate and improve wettability. It is known that the optimal wetting effect (minimum surface tension) is observed only after some time after the solution of the active substance, which must be taken into account in the dynamic process of washing the gas turbine engine.

Emulsions are systems in which both the dispersed phase and the dispersion medium are in a liquid state. Only oil-in-water emulsions in which the hydrophobic part is dispersed in the aqueous medium in the form of drops are important for the cleaning and cleaning action. Emulsions can be formed spontaneously and forcibly, by mechanical interaction or phase fragmentation. They are characterized by low surface tension at the interface, which is achieved by the action of surfactants. The formation of the emulsion and its stability depend on many factors, including the presence of various additives, the ability of the third phase to adsorb droplets, reducing the potential difference, etc. In the process of washing the flow part, this process will determine the composition and concentration of surfactants in the detergent.

The basis of dispersion, peptization and suspension is the same process, which consists in the fragmentation of conglomerates of contaminants and their retention in the liquid phase.

Peptization is the transfer to a colloidal solution of a solid (contamination) using a suitable reagent peptizer.

Suspension is a coarsely dispersed system of contaminant particles in an aqueous medium. During suspension and dispersion, conglomerates of aggregated particles of contaminants are peptized, detached from the surface of the blades and go into the milled state of the detergent solution. A number of surfactants provide spontaneous dispersion of agglomerated particles.

The reduction of surface tension as a result of the adsorption of the surfactant has a crushing and peptizing effect on the adsorbed phase. The peptenizing medium is held by surface forces on the surface of colloidal particles, so that its pressure increases so much that there is a disintegration (destruction) of the particles. This process is one of the most important in the process of the flowing part washing.

The process of foaming when cleaning metal surfaces by jet or mechanical method does not increase the cleaning effect, but often has a negative effect, because the formation of foam consumes part of the surfactant, and the cleaning effect of foam in these cases is insignificant.

Solubilization - the process of dissolving in solutions of surfactants at a certain concentration of liquid or solid substances that are insoluble in water. Without considering the physico-chemical aspects of this phenomenon, we note that this phenomenon is used for the introduction 


\section{ЕНЕРГЕТИЧНЕ МАШИНОБУДУВАННЯ № 1-2021}

of solvents into detergent solutions, which increase the efficiency of removing contaminants. In addition, in some cases, this provides stabilization of detergent emulsions.

Detergent action is characterized by the ability of a product to remove contaminants of different composition. The theory of detergent action has not yet been developed [1, p. 88; 4, p. 268]. The end result of the cleaning process depends on many factors: the properties of the surface to be cleaned, the nature and intensity of contaminants, the composition of the detergent and its concentration, the degree of water hardness, temperature, mechanical impact and many others. Therefore, even a brief analysis of the phenomena occurring in the washing process gives grounds to claim that high efficiency can be not individual detergents, and their compositions. The use of compositions is also explained by economic, physicochemical and environmental reasons. Often expensive and scarce surfactants can be replaced by cheaper compositions. In other cases, the use of certain surfactants can cause corrosion or environmental damage. In some cases, the addition of mineral and organic products to surfactants enhances their effect, and sometimes weakens.

There are few theoretical works on the composition and application of surfactants in compositions, as well as reviews of surfactant compositions, so consider some aspects of this problem.

As a detergent, surfactants are used for a number of processes. To stabilize liquid contaminants in the volume of detergent solution is required $\Gamma_{m} S_{\mathrm{e}}$ mole of surfactant (where $\Gamma_{m}-$ marginal adsorption of surfactants, $S_{\mathrm{e}}$ - the total surface area of the emulsion), as the emulsion stabilizes only the boundary adsorption layers [1, p.90]. The surface of the cleaning blades $S_{\text {л }}$ is covered with a layer of surfactants in the amount $\Gamma_{l} S_{l}$. Part of the surfactant (equilibrium concentration) remains in the phase volume $\left(C_{m} V_{p}\right)$. The formation of foam consumes surfactants in quantities $\Gamma_{m} S_{\mathrm{f}}\left(S_{\mathrm{f}}-\right.$ foam surface). To stabilize the solid contaminants $\Gamma_{\mathrm{s}} S_{\mathrm{s}}\left(\Gamma_{\mathrm{s}}-\right.$ adsorption of surfactants on the surface of suspensions, $S_{\mathrm{s}}$ - the surface area of the suspension) is required. The amount of surfactant adsorbed on other parts of the flowing part can be neglected, because its area is several times smaller than the area of the blades. Then the total cost of the surfactants will be:

$$
M=\Gamma_{m} S_{\mathrm{e}}+\Gamma_{m} S_{\mathrm{f}}+\Gamma_{1} \mathrm{~S}_{1}+C_{m} V_{p}+\Gamma_{\mathrm{s}} S_{\mathrm{s}} .
$$

The composition may include several surfactants, inorganic salts, organic solvents, electrolyte solutions, corrosion inhibitors, defoamers and other impurities.

The composition depends on the properties of the contaminants, the surfactants used and the characteristics of the process. Currently, a number of detergents are used to flush the flowing part. None of these tools is optimal in composition, which confirms their analysis.
«Aerol» is designed to remove oily and soil contaminants, as well as soot from the surface of the aircraft skin at positive temperatures $[5$, p. 62]. Composition in percentage:

1. Disodium ester of sulfosuccinic acid anionic surfactant $\mathrm{ROOCCHSO}{ }_{3} \mathrm{Na}-\mathrm{CH}_{2} \mathrm{COONa}-25 \ldots 30$.

2. $\mathrm{Na}_{2} \mathrm{CO}_{3}$ - provides the $\mathrm{pH}$ of the solution within $12 \ldots 13$

3. Synthetic fatty acids $\mathrm{C}_{7}-\mathrm{C}_{9}$ emulsifier $-18 \ldots 20$.

Aerol is an excellent detergent for washing fabrics and removing with a stiff brush dirt from painted surfaces, non-toxic and environmentally friendly. Can be used without heating $\left(25 \pm 2^{\circ} \mathrm{C}\right)[3, \mathrm{p} .171]$.

Pollution removal efficiency, which is evaluated as the ratio of the mass of contamination removal after the washing cycle to the initial (before washing): $E=\frac{M_{H}-M_{K}}{M_{K}} \cdot 100 \%$, when rinsing on low gas for 5 minutes and a flow rate of $1.21 / \mathrm{min}$ for the emulsion was the maximum. Data on the detergency of the various compositions are shown in table 1 .

Table 1. Comparative efficiency of detergent compositions

\begin{tabular}{|c|c|c|c|c|c|c|}
\hline $\begin{array}{c}\text { Detergent } \\
\text { composition }\end{array}$ & Lotos & Aerol & $151-\mathrm{K}$ & & & \\
\hline $\min$ & $151-\mathrm{K}$ & & & & & \\
\hline $\max$ & $151-\mathrm{T}$ & $151-\mathrm{P}$ & & & & \\
\hline$(\%)$ & $68 \%$ & $78 \%$ & $82 \%$ & $98 \%$ & $92 \%$ & $96 \%$ \\
\hline
\end{tabular}

The labels min and max mean the minimum and maximum content of components in the composition, respectively. As part of "151-T" gas is replaced by trichlorethylene, in the composition "151-P" perchlorethylene. Except as indicated, the compositions corresponded to the composition " $151-K$ ".

Increasing the washing time to 600 seconds increases the washing efficiency of the detergnt "Lotos" до 88\%, Aerol- 95\%. Emulsions "151-K", "151-T", “151-П" provide complete removal of contaminants.

\section{TECHNOLOGY OF WASHING THE FLOWING PART OF THE GAS TURBINE ENGINE}

The concept of washing technology should include the method of introducing the detergent composition into the flow part of the gas turbine engine, the mode of operation of the engine during washing, the choice of the optimal temperature of the solution and the duration of the washing process. When developing washing technology it is necessary to take into account not only the technical aspect (quality of washing) but also economic. That is, it is necessary to determine the optimal duration of washing and its frequency for the life of the gas turbine engine in operation [1, p. 78].

After selecting the optimal washing mode, which is characterized by the engine rotor speed and the parameters of the cleaning solution (spray dispersion, fluid consumption and its chemical composition), it is 
necessary to determine the washing duration. The choice of the optimal washing time is associated with both the maximum cleaning and the minimum flow rate during engine operation during washing.

In determining the duration of washing in terms of maximum cleaning of the surface of structural elements, the method used in [5, p. 17] was used. As the main assumption in this case it is necessary to consider that deposits on a surface of constructive elements are considered as a covering. Then the task is to determine the erosion of the coating. Erosion is characterized by three parameters: the duration of the latent period, the amount of mass wear after the end of the latent period and the total amount of mass wear.

In determining the duration of the latent period, we use the model presented in [6, p. 312], according to which the time of the latent period of erosion is determined by sequentially calculating the following values.

1. Impact pressure:

$$
P=\frac{\rho_{c} C_{c} W \cos \theta}{1+\rho_{L} C_{L} / \rho_{c} C_{c}}
$$

where $\rho_{c}, \rho_{L}$ - according to the density of deposits and detergent solution; $C_{c}, C_{L}-$ speed of sound, respectively, for deposits and detergent solution; $W$ the relative velocity of the drops of detergent solution; $\theta$ - the angle between the vector of relative velocity and normal line to the surface of the structural element.

2 . The average pressure on the surface contamination [7, p. 87]:

$$
\sigma_{0}=P \frac{1+\psi_{s c}}{1-\psi_{s c} \psi_{L c}}\left[1-\psi_{S C} \frac{1+\psi_{L c}}{1+\psi_{s c}} \frac{1-\exp (-\gamma)}{\gamma}\right],
$$

where $\psi_{s c}=\frac{Z_{s}-Z_{c}}{Z_{s}+Z_{c}} ; \psi_{L c}=\frac{Z_{L}-Z_{c}}{Z_{L}+Z_{c}} ;$

$Z_{L} ; Z_{c} ; Z_{s}$ - accordingly, dynamic total impedances $(Z$ $=\rho C$ ) detergent, dirt and substrate (structural element of the material);

$$
\gamma=\frac{C_{0}}{C_{L}} \frac{d}{h c} \frac{1+\left(Z_{L} / Z_{c}\right)}{1+\left(Z_{c} / Z_{s}\right)}\left[\frac{2}{1+\left(Z_{L} / Z_{c}\right)}\right]-
$$

dimensionless parameter; $h_{c}-$ the thickness of the contamination; $d$ - the diameter of the drop of detergent solution; $C_{0}$-speed of sound for the substrate material.

3. The numbers of reflection of voltage waves in the contamination during the impact [7, p. 125]

$$
\bar{K}=K_{l}=\frac{1}{1-\psi_{s c} \psi_{L c}} .
$$

4. Effective strength characteristics for film contamination:

$$
S_{l c}=\frac{4 \sigma_{l c}(b c-1)}{1-2 \mu_{c}} \frac{1}{1+2 \bar{n} \psi_{s c}},
$$

where $\mu_{c}-$ Poisson's ratio; $b_{c}-$ the value used in the calculations is equal to 20,$9 ; \sigma_{l c}$ - average preassure in contamination.
5. The number of strokes per «spot» during the latent period:

$$
n_{i c}=\frac{8,9}{d^{2}}\left(\frac{S_{l c}}{\sigma_{0}}\right)^{5,7} .
$$

6. Number of drops per unit volume of air:

$$
q=\frac{6 V}{\pi d^{3}}
$$

where $V$ - volume of liquid per unit volume of air.

7. Time latent period:

$$
t_{i c}=\frac{n_{i c}}{q W \cos \theta} .
$$

8. Wear rates of mass per unit area per unit time after the end of the latent period:

$$
\begin{gathered}
\alpha_{c}=0,04 \rho_{c} \frac{W \cos \theta}{V t} I\left(\frac{\bar{\sigma}_{0}}{S_{l c}}\right)^{4}, \text { or } \\
\alpha_{c}=7,5410^{-5} \rho_{c} d^{3} q W \cos \theta\left(\frac{\bar{\sigma}_{0}}{S_{l c}}\right)^{4} .
\end{gathered}
$$

In accordance with the above method, the time of removal of contamination from the surface of the blades of the fan of the two-circuit motor was calculated. The calculation used the data on the characteristics of the films of sediments (contaminants), given in [7, p. 213]. The total time required to remove contaminants (washing time) was determined by the formula obtained from the equations for determining the time of the latent period $t_{i c}$ and mass wear rate $\alpha_{c}$ :

$$
t_{\Sigma}=\frac{n_{i c}}{q W \cos \theta}+7,54 \cdot 10^{-5} d^{3} W \cos \theta\left(\frac{\bar{\sigma}_{0}}{S_{l c}}\right)^{4} \frac{l}{\delta},
$$

where $\delta$ - the thickness of the film of contamination.

Calculation of the washing time $t_{\Sigma}$ was performed for a wide range of fineness of the spray of the detergent solution $\left(d=1 \cdot 10^{-8} \ldots 3 \cdot 10^{-6} \mathrm{~m}\right)$. The average washing time for a given range of detergent droplet diameters and the selected range of engine operating modes was $t_{\Sigma}=4,7 \mathrm{~min}$.

Thus, given methods make it possible to determine the optimal mode and duration of contamination.

On the backs of the blades, where in the first place there is a disruption of the flow, the deposits are thicker and are $5 \ldots 6$ microns. In the area of bandage shelves, the layer thickness increases to $8 \ldots 10 \mu \mathrm{m}$. At the same time on the troughs of the blades the thickness of the layer of sediments did not exceed $2 \ldots 3 \mu \mathrm{m}$.

Removal of pollution provides updating of parameters of the fan and compressors of an internal contour. As shown in Fig. 2, after washing $\pi^{*}{ }_{v}$ grew on average by $1.4 \%$. Simultaneously with growth $\pi_{\mathrm{v}}^{*}$ the air consumption in the engine also increases.

The improvement of the low-pressure spool and high-pressure spool characteristics as a result of washing the flowing part is shown by the test results 


\section{ЕНЕРГЕТИЧНЕ МАШИНОБУДУВАННЯ № 1-2021}

of the engine in Fig. 3, 4. Increasing the parameters of the fan and compressors of the internal circuit after washing is accompanied by an increase in total pressure at the nozzle cut $p^{*}$.

In particular, on the batch of engines $\mathrm{p}_{\mathrm{c}}{ }_{\mathrm{c}}$ increased by $0.47 \%$ on low gas with increasing $\pi^{*}{ }_{6, \lambda}$ of $0,5 \%$.

Increasing the pressure in the flowing part of the engine, in particular at lower modes, contributes to an increase in the stock of the on pop operations, that is a kind of unstable fan operation, in which case you need to stop the takeoff of the aircraft. It is known that in order to prevent the manifestation of this type of unstable operation, the flight manual of this type of engine does not allow starting the engine and taxiing the aircraft with a passing wind above $5 \mathrm{~m} / \mathrm{s}$ and crosswind more than $17 \mathrm{~m} / \mathrm{s}$.

Analysis of research results before and after washing of a large batch of engines NK-8-2U [3, p. 170, 8, p. 44] allowed to establish the dependence of the increase in fuel consumption $\Delta G_{\mathrm{T} .4}$ from the degree of contamination of its flowing part; it has a form

$$
\Delta G_{h f}=\Delta G_{h f \cdot \max }(\tau / T)^{m}
$$

where $\Delta G_{h f}=G_{h f}-G_{h f 0}-$ increase in hourly fuel consumption; $\Delta G_{h f 0}$ - hourly fuel consumption of a new engine (or after repair); $T, \mathrm{~h}$ - engine life; $\tau, \mathrm{h}$ - engine operating time (new, or after pre-washing); $\mathrm{m}$ is an indicator of the degree that characterizes the growth rate of fuel consumption when contaminating the flowing part. According to the results of processing the entire array of experimental data, the value of the indicator is obtained $m=0,4034$.

The optimal frequency of washing of the flowing part was determined from the conditions of ensuring maximum economic efficiency [6, p.351]

$$
E=Q C_{m}-E p \cdot \kappa,
$$

where $Q$ - fuel savings at $\mathrm{K}$ washing per resource, determined by the formula

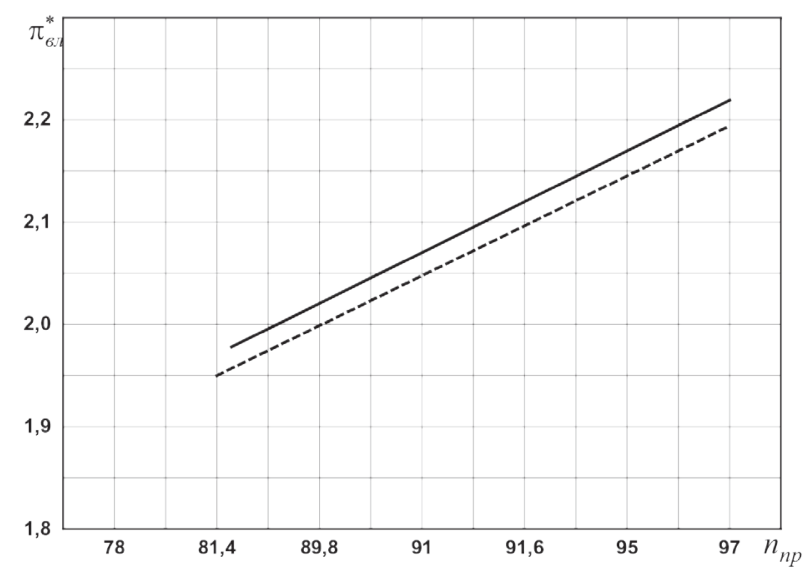

Fig. 2. Changing the compression ratio of the fan

$$
Q=\frac{\Delta G_{h f \cdot \max } T}{m+1}\left[1-\frac{1}{(k+1)^{m}}\right] .
$$

$C_{m}$ - price of one ton of fuel, $\$ / \mathrm{t}, E_{p . \kappa}$ - operating costs for washing one engine. The optimal number of washes per resource is determined by the results of the analysis for the extremum of the function $Q=f(K)$ :

$$
K_{o p t}=\left[\frac{C_{m}}{E_{p}} \Delta G_{h f \cdot \max } T \frac{m}{m+1}\right]^{\frac{m}{m+1}}-1 .
$$

As shown by the analysis of changes in engine characteristics from the influence of a single operating factor (in this case - the removal of contamination of the flowing part of the compressor), an effective method of estimating the growth of basic data of the engine installed on the aircraft is the measurement of operating modes during engine tests before and after the technological operation. As shown by the results of bench studies of double-circuit engines with flow mixing, the relative increase in thrust and specific fuel consumption after the technological operation is described by the relations:

1 ) in the subcritical mode of leakage from the nozzle

$$
\delta P_{n p}=\frac{\left(\frac{p_{i}^{*}}{p_{H}}\right)^{\frac{k-1}{k}}-\left(\frac{p_{i}^{*}}{p_{H}}\right)_{1}^{\frac{k-1}{2}}}{\left(\frac{p_{i}^{*}}{p_{H}}\right)^{\frac{k-1}{k}}-\frac{1}{K_{i}^{\frac{k-1}{k}}}} .
$$

2) in the supercritical mode of leakage from the nozzle

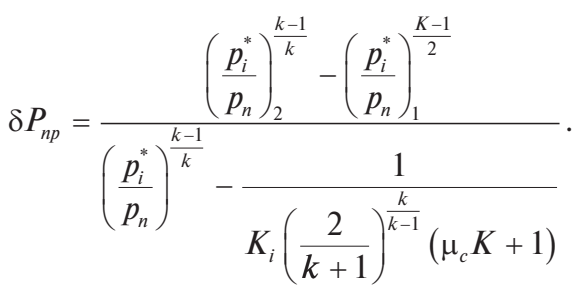

where $p_{i}^{*}-$ full pressure at the nozzle section, measured at a fixed point; $K_{i}-$ a factor that establishes the relationship

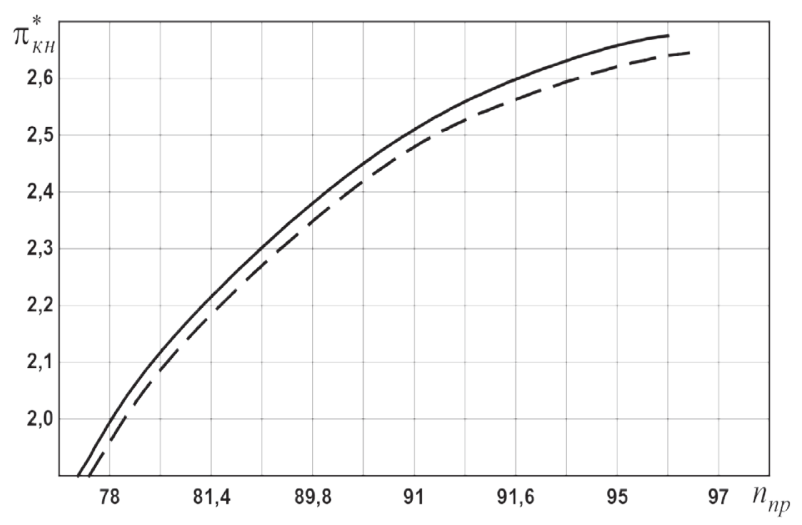

Fig. 3. Changing the compression ratio of the low-pressure spool 


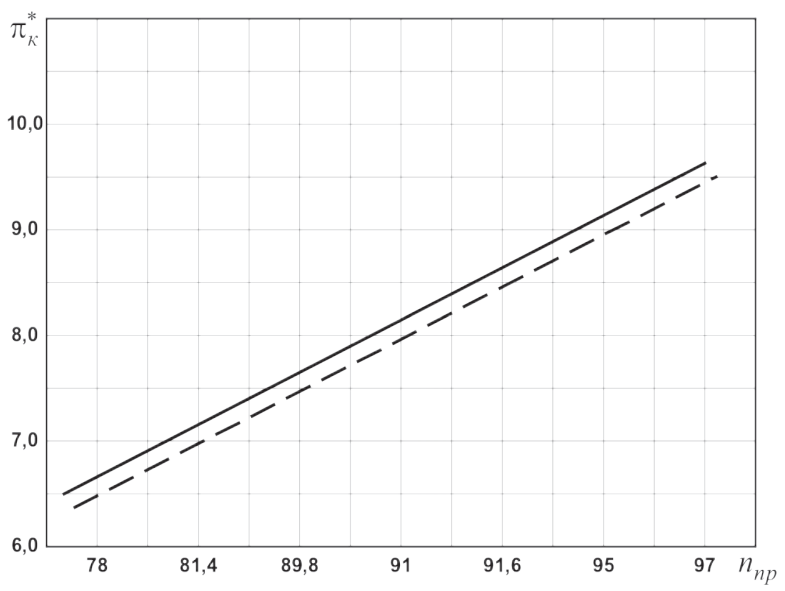

Fig. 4. Total change of the compression ratio

between local pressure and the average cross-sectional pressure of the inhibited flow. $K_{i}$ linearly depends on the speed of the rotor of the high pressure motor within $0.98<\mathrm{Ki}<1.07 . \mu_{c}-$ the flow rate of the nozzle, which depends on its taper [2, p. 17], $\left(\frac{p_{i}^{*}}{p_{n}}\right)_{1} ;\left(\frac{p_{i}^{*}}{p_{n}}\right)_{2}-$ the ratio of pressure, which was measured in the first and second experiments at the same modes.

The relative increase in specific fuel consumption is equal to

$$
\delta C_{\text {num }}=\Delta G_{h f}-\Delta p_{n p},
$$

where $\Delta G_{h f}=\frac{\Delta G_{h f 2}-\Delta G_{h f 1}}{\Delta G_{h f 1}}-$ relative increase in time fuel consumption.

When you open the tap 3 , the concentrated detergen under pressure from the cylinder 7 is displaced into the mixer 2. The tangential introduction of water into the mixer provides good mixing of the concentrated detergent with water. Changing the concentration of the concentrated detergent solution is provided by changing the pressure drop in the displacement system and in the water supply system, controlled by manometers 4 and 6 . Changing the pressure from 15 to $0.6 \mathrm{MPa}$ is provided by the reducer 9 .

The proposed method for cleaning the flow part of aviation gas turbine engines does not require preparation of the elements of the flow part and complex tooling. The principle of operation of the installation is as

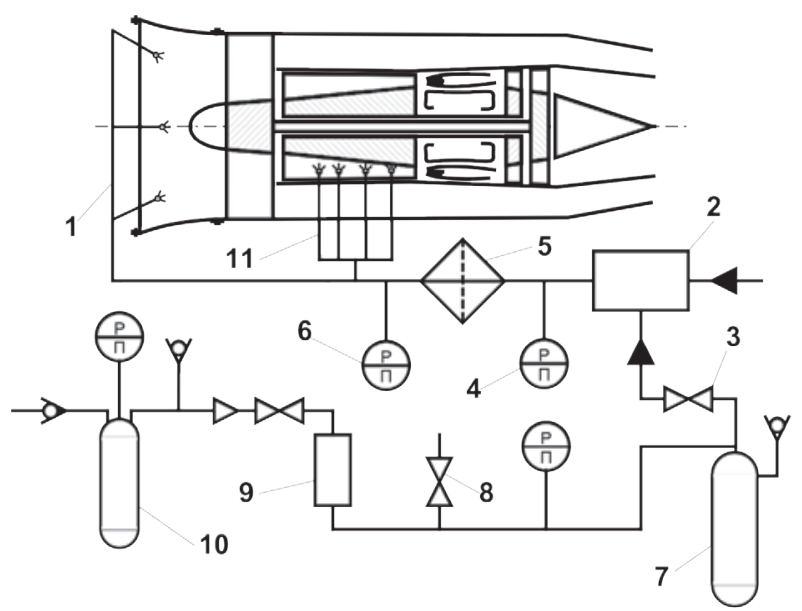

Fig. 5. Installation diagram for warshing the flowing part of the gas turbine engine

follows. Heated to a temperature of $50-80^{\circ} \mathrm{C}$ boiled water is fed from the tanker of the aircraft through a hose to the fitting of the centrifugal mixer 2.

The solution formed in the system through the filter 5 is fed to the distribution manifold (nozzle ring) 1 and the nozzles 11 of the supply of detergent solution to the compressor. Washing of the flowing part of the gas turbine engine is carried out with alternating supply of detergent solution and clean water when the engine is running in the mode of cold scrolling. At the end of the work, the air pressure in the cylinder 10 is reduced to atmospheric by opening of the valve 8 .

\section{CONCLUSIONS}

1. Detergents are considered and the optimal detergent composition is selected.

2. Amethod for determining the optimal washing time, which takes into account the properties of contaminants of the flow part of the GTE and detergents is developed.

3. The technology of washing the flowing part of the GTE is developed and it is based on the obtained data on the optimal washing time.

4. The method of calculation of periodicity of washing of GTE during its interrepair resource is presented.

5. The installation for washing of a flowing part of TFE in operating conditions is offered.

\section{REFERENCES}

[1] Kulik, N.S. (1993). Parametricheskie metodyi otsenki tehnicheskogo sostoyaniya aviatsionnyih GTD [Parametric methods for assessing the technical condition of aircraft GTE]. Kiev: KIIGA. [in Russian].

[2] Osik, V.M., Panin, V.V. (1999) Otsenka vliyaniya izmeneniya geometricheskih razmerov elementov GTD v ekspluatatsii na ee gazodinamicheskuyu ustoychivost [Estimation of the influence of changes in the geometrical dimensions of the elements of the GTD in exploitation on its gas-dynamic stability]. Vestnik Kievskogo mezhdunarodnogo universiteta grazhdanskoy aviatsii. \# 1. PP. 15-20. [in Russian].

[3] Volyanskaya, L.G., Panin, V.V., Sung Gaoyun (2005). Metodyi i sredstva povyisheniya gazodinamicheskoy ustoychivosti kompressorov gazoturbinnyih dvigateley [Methods and means of increasing the gas-dynamic stability of gas turbine engine compressors]: monografiya. Kiev: NAU, 2005. [in Russian].

[4] Zimon, A.D. (1974). Adgeziya zhidkosti i smachivaniya [Adhesion of the liquid and wetting]. Moskva: Himiya. [in Russian]. 


\section{ЕНЕРГЕТИЧНЕ МАШИНОБУДУВАННЯ № 1 2021}

[5] Gorbanovskiy, V.B., Panin, V.V., Chumak, O.I. (1999) Metod kolichestvennoy otsenki zagryazneniya elementov protochnoy chasti PS-90A [Method of quantitative estimation of contamination of elements of flow part of PS-90A]. Kiev: KIIGA. [in Russian].

[6] Petunin, A.N. (1996) Metodyi i tehnika izmereniya parametrov gazovogo potoka [Methods and technique of measuring the parameters of the gas flow]. Moskva: Mashinostroenie. [in Russian].

[7] Tereschenko, Yu.M., Mitrahovich, M.M. (2001) Aviatsionnyie gazoturbinnyie dvigateli [Aviation gas turbine engines]. Kiev: KVITs. [in Russian].

[8] Olali, N.V., Olali, M.O., Orukari, M., Jumbo, E.E. (2018) A model of compressor blades contamination in aviation GTE in operation. Vcheni zapysky Tavriiskoho natsionalnoho universytetu imeni V.I. Vernadskoho. №6. Vol.29(68).

\section{BIBLIOGRAPHY}

[1] Кулик Н.С. (1993). Параметрические методы оценки технического состояния авиационных ГТД. Киев : КИИГА.

[2] Осик В.М., Панин В.В. (1999) Оценка влияния изменения геометрических размеров элементов ГТД в эксплуатации на ее газодинамическую устойчивость. Вестник Киевского международного университета гражданской авиации. № 1. С. 15-20.

[3] Волянская Л.Г., Панин В.В., Сунг Гаоюнь (2005). Методы и средства повышения газодинамической устойчивости компрессоров газотурбинных двигателей: монография. Киев : НАУ, 2005. 200 с.

[4] Зимон А.Д. (1974). Адгезия жидкости и смачивания. Москва : Химия.

[5] Горбановский В.Б., Панин В.В., Чумак О.И. (1999) Метод количественной оценки загрязнения элементов проточной части ПС-90А. Киев : КИИГА.

[6] Петунин А.Н. (1996) Методы и техника измерения параметров газового потока. Москва : Машиностроение.

[7] Терещенко Ю.М., Митрахович М.М. (2001) Авиационные газотурбинные двигатели. Киев : КВИЦ.

[8] Olali N.V., Olali M.O., Orukari M., Jumbo E.E. (2018) A model of compressor blades contamination in aviation GTE in operation. Вчені записки Таврійського національного університету імені В.I. Вернадського. № 6. Vol. 29(68).

(C) Олалі М. О., Осайсай Е. Ф., Олалі Н. В. Дата надходження статті до редакції: 11.03 .2021 Дата затвердження статті до друку: 25.03.2021 